\title{
Pengaruh Lama Pengobatan Awal Sindrom Nefrotik terhadap Terjadinya Kekambuhan
}

\author{
Partini P Tribono, Eva Miranda Marwali, Husein Alatas, Taralan Tambunan, Sudung O Pardede
}

\begin{abstract}
Sebagian besar sindrom nefrotik pada anak memberikan respons yang baik pada pengobatan awal dengan steroid. Namun sekitar $57 \%$ di antaranya menunjukkan kekambuhan berulang yang memerlukan pengobatan steroid yang berulang-ulang, hingga sebagian menunjukkan efek toksik. Pemberian steroid awal yang lebih lama dapat mengurangi jumlah pasien yang mengalami kambuh sering. Di Bagian Ilmu Kesehatan Anak FKUI-RSCM telah dilakukan penelitian uji klinik terhadap 2 kelompok pasien baru sindrom nefrotik. Kelompok I mendapat terapi steroid $60 \mathrm{mg} / \mathrm{m} 2 / \mathrm{hari}$ (FD) selama 4 minggu yang dilanjutkan dengan dosis $40 \mathrm{mg} / \mathrm{m} 2 /$ hari selang sehari (AD) selama 4 minggu, sedang kelompok II mendapat terapi steroid FD dan AD masing-masing selama 6 minggu. Terhadap kedua kelompok tersebut diikuti selama 1 tahun untuk melihat kekeraban kekambuhannya. Dalam tahun 1994-1998 terdapat 35 anak yang memenuhi kriteria inklusi, namun hanya 18 anak (10 anak kelompok I dan 8 anak kelompok II) yang menyelesaikan terapi dan ikut dalam observasi selama 1 tahun. Tidak didapatkan perbedaan klinis dan laboratoris pada kedua kelompok tersebut. Kekambuhan pertama kali timbul dalam 4 minggu setelah pengobatan pada 2 dari 8 (25\%) anak kelompok II dan 3 dari 10 (30\%) anak kelompok I. Kekambuhan lebih dari 2 kali atau lebih dalam 6 bulan pertama setelah pengobatan terdapat pada 4 (40\%) anak kelompok I dan $2(25 \%)$ anak kelompok II, sedangkan kekambuhan 4 kali atau lebih dalam 1 tahun setelah pengobatan tidak ditemukan pada kelompok II, namun didapatkan pada $2(20 \%)$ anak kelompok I. Terdapat 1 (10\%) anak kelompok I dan 2 (25\%) anak kelompok II yang tidak pernah kambuh. Disimpulkan bahwa sindrom nefrotik yang mendapat terapi steroid awal lebih lama (12 minggu) mempunyai kecenderungan lebih jarang kambuh bila dibandingkan dengan kasus yang mendapat terapi steroid awal lebih pendek (8 minggu).
\end{abstract}

Kata kunci: sindrom nefrotik, steroid, remisi, kambuh, kesintasan.

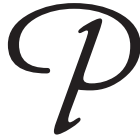

engobatan kortikosteroid pada sindrom nefrotik anak telah dilakukan sejak tahun 1950. Demikian pula telah dilakukan berbagai studi kolaboratif untuk menguji efektivitas kortikosteroid jangka panjang. Pada umumnya sebagian besar $( \pm 80 \%)$ memberikan respon yang baik pada pengobatan awal. Akan tetapi sekitar

\footnotetext{
Alamat Korespondensi: Dr. Partini P Trihono, SpA(K). Staf Subbagian Nefrologi. Bagian Ilmu Kesehatan Anak FKUI-RSCM. Jl. Salemba no.6, Jakarta 10430.

Telepon: 021-3915179. Fax: 021-390 7743.
}

57\% diantaranya menunjukkan kambuh berulang yang memerlukan pengobatan steroid yang berulang - ulang, hingga sebagian menunjukkan efek toksik. Bahkan 5\% kemudian tidak memberikan respon lagi (late non responder).

Berbagai studi kolaboratif telah dilakukan untuk membuktikan bahwa pemberian terapi steroid awal yang lebih lama dari pengobatan standar sesuai ISKDC (8 minggu) 2 dapat mengurangi jumlah penderita sindrom nefrotik yang kambuh sering. ${ }^{3,4,5}$ Menurut Brodel (1991) kira-kira 80\% anak kambuh dalam satu tahun apabila prednison diberikan untuk 4 minggu, $60 \%$ kambuh sesudah pengobatan 8 minggu, dan 
hanya 36\% kambuh apabila prednison diberikan selama 12 minngu. ${ }^{3}$

Berdasarkan hasil penelitian di atas dilakukan penelitian uji klinik untuk menilai pengaruh lama pengobatan awal sindrom nefrotik terhadap terjadinya kekambuhan.

\section{Metoda}

Penelitian uji klinik ini adalah bagian dari penelitian studi kolaboratif pengobatan kortikosteroid pada sindrom nefrotik anak oleh Unit Kerja Koordinasi Nefrologi Ikatan Dokter Anak Indonesia. Penelitian ini dilakukan di Subbagian Nefrologi Anak Bagian Ilmu Kesehatan Anak FKUI-RSCM sejak tahun 19941998, terhadap penderita sindrom nefrotik anak yang merupakan sindrom nefrotik primer yang baru pertama kali diderita dan belum pernah mendapat pengobatan steroid atau obat imunosupresif lain. Kriteria inklusi yaitu ditemukan edema, proteinuria $>$ $40 \mathrm{mg} / \mathrm{m} 2 /$ jam, hipoalbuminemia $(<2,5 \mathrm{~g} / \mathrm{dl})$, kolesterol $>250 \mathrm{mg} \%$, umur antara 12 bulan dan 16 tahun, tidak ditemukan tanda - tanda nefritis seperti hematuria, hipertensi dan laju filtrasi glomerulus (klirens kreatinin) normal (>68 ml/menit/1,73 m2), serta tidak menderita penyakit lain seperti Sistemik Lupus Eritematosus, Diabetes melitus, sindrom Henoch Schonlein, Malaria, Sifilis, Amiloidiosis dan penyakit metabolik lainnya.

Subjek penelitian secara acak dibagi dalam dua kelompok penelitian. Kelompok I yang mendapat terapi steroid jangka pendek ( 8 minggu) yaitu selama 4 minggu pertama dosis $60 \mathrm{mg} / \mathrm{m} 2 /$ hari (FD) dibagi dalam 3 dosis, dengan dosis maksimum $80 \mathrm{mg} / \mathrm{hari}$. Dilanjutkan 4 minggu kedua dengan dengan dosis 40 $\mathrm{mg} / \mathrm{m} 2 /$ hari selang sehari (AD) pada pagi hari. Kelompok II mendapat terapi steroid dosis FD dan AD masing-masing selama 6 minggu. Dosis steroid dihitung berdasarkan berat badan tanpa edema. Banyaknya edema dinilai pada setiap pasien dengan perhitungan edema anasarka $30 \%$ berat badan, edema pelpebra $10 \%$ berat badan, edema palpebra dan tibial $20 \%$ berat badan.

Pada kedua kelompok penelitian ini diidentifikasi anak yang menyelesaikan terapi dengan taat dan yang sensitif terhadap pengobatan awal steroid, serta tidak mengalami efek samping steroid. Semua anak yang memenuhi kriteria ini diikuti selama 1 tahun. Anak yang resisten steroid, toksik steroid atau dependen steroid pada pengobatan awal tidak diikutkan dalam penelitian. Anak yang tidak dapat diikuti selama 12 bulan atau meninggal dunia atau mengalami resisten steroid, toksik steroid, dan tergantung steroid setelah pengamatan 12 bulan setelah terapi awal dianggap drop out. Selama satu tahun dilakukan peniliaian dengan membandingkan kedua kelompok penelitian terhadap saat terjadinya remisi pertama kali setelah pengobatan awal, saat timbulnya kekambuhan pertama kali, dan jumlah kekambuhan dalam waktu 6 bulan dan 12 bulan pasca terapi. Analisis kesintasan terhadap terjadinya kekambuhan dilakukan pada kedua kelompok penelitian.

Kriteria remisi yaitu bila proteinuria negatif atau trace, atau protein kuantitatif urin $<4 \mathrm{mg} / \mathrm{m} 2 /$ jam pada 3 hari berturut - turut dalam 1 minggu. Kriteria kambuh bila proteinuria positif 1 atau lebih pada 3 hari berturut - turut dalam 1 minggu atau $>4 \mathrm{mg} /$ $\mathrm{m} 2 /$ jam. Bila hal ini bersamaan dengan terjadinya infeksi sebaiknya infeksi dihilangkan dulu dengan antibiotik dan kemudian pasien dinilai kembali. Kriteria kambuh sering adalah kambuh yang terjadi 2 kali atau lebih dalam 6 bulan pertama atau 4 kali lebih dalam 1 tahun. Sensitif steroid yaitu remisi timbul dalam 8 minggu pengobatan steroid. Resisten steroid yaitu tidak timbul remisi dalam 8 minggu pengobatan steroid. Toksik steroid yaitu timbul efek samping steroid pada saat pengobatan dengan steroid. Dependen steroid yaitu kekambuhan yang timbul pada saat dosis steroid diturunkan atau timbul dalam waktu 2 minggu setelah steroid dihentikan dan keadaan ini berulang selama 2 hari berturut - turut.

\section{Hasil}

Dalam kurun waktu 1994-1998 terdapat 35 anak yang memenuhi kriteria inklusi, namun hanya 18 anak (10 anak kelompok I dan 8 anak kelompok II) yang dapat menyelesaikan terapi awal steroid dengan taat dan semuanya sensitif pada pengobatan steroid. Pada kelompok I terdapat 3 anak yang tidak menyelesaikan terapi, 1 anak dengan tidak taat, 2 anak dengan resisten steroid awal, 2 anak dependen steroid awal, dan 1 anak toksik steroid. Pada kelompok II terdapat 4 anak yang tidak meyelesaikan terapi dan 4 anak tidak taat.

Gambaran klinis dan hasil pemeriksaan penunjang dari 18 anak pada kedua kelompok penelitian saat awal 
diagnosis dapat dilihat pada Tabel 1. Edema timbul pertama kali kebanyakan pada 7-14 hari pada kelompok I, dan kurang dari 7 hari pada kelompok II. Edema anasarka terdapat pada 9 anak (90\%) kelompok I dan 4 anak (50\%) kelompok II. Tidak terdapat perbedaan hasil laboratorium darah tepi, urin lengkap, albumin, globulin, kolesterol total dan kreatinin pada kedua kelompok. Kadar ureum tidak berbeda pada dilakukan pada semua anak dalam penelitian ini.

Sembilan puluh persen anak kelompok I dan $75 \%$ anak kelompok II mencapai remisi pada 4 minggu pertama. Kekambuhan pertama kali timbul dalam 4 minggu pertama setelah pengobatan pada 3 anak (30\%) kelompok I dan 2 anak (25\%) kelompok II, pada 4 minggu kedua pada 2 anak (20\%) kelompok I dan 2 anak (25\%) kelompok II, dan 4 minggu ketiga

Tabel 1. Gambaran klinis dan pemeriksan penunjang Sindrom Nefrotik pada awal diagnosis

\begin{tabular}{|c|c|c|}
\hline & Kelompok I & Kelompok II \\
\hline Jumlah kasus & 10 & 8 \\
\hline \multicolumn{3}{|l|}{ Jenis kelamin } \\
\hline laki-laki & 7 & 6 \\
\hline perempuan & 3 & 2 \\
\hline Umur & $\begin{array}{l}18 \text { bulan }-11 \text { tahun } \\
\text { rerata }(75 \pm 57) \text { bulan }\end{array}$ & $\begin{array}{l}18 \text { bulan }-7 \text { tahun } \\
\text { rerata }(51 \pm 33) \text { bulan }\end{array}$ \\
\hline \multicolumn{3}{|l|}{ Timbulnya edema pertama kali } \\
\hline$<7$ hari & 4 & 3 \\
\hline $7-14$ hari & 5 & 2 \\
\hline $14-30$ hari & 1 & 2 \\
\hline Tidak ada data & 0 & 1 \\
\hline \multicolumn{3}{|l|}{ Edema saat awal diagnosis } \\
\hline Anasarka & 9 & 4 \\
\hline Palpebra dan Pretibial & 0 & 2 \\
\hline Pretibial & 1 & 0 \\
\hline Tanpa edema & 0 & 1 \\
\hline Tidak ada data & 0 & 1 \\
\hline \multicolumn{3}{|l|}{ Pemeriksaan Lab. Darah } \\
\hline Protein urin $:+4$ & 1 & 0 \\
\hline+3 & 4 & 4 \\
\hline+2 & 2 & 2 \\
\hline+1 & 3 & 1 \\
\hline Albumin ( $\mathrm{g} / \mathrm{dl})$ & $1,03-2,40 \quad(1,71)$ & $1,01-2,63 \quad(1,71)$ \\
\hline Globulin ( $\mathrm{g} / \mathrm{dl}$ ) & $1,80-4,29(3,04)$ & $1,49-3,40 \quad(2,56)$ \\
\hline Kolesterol ( g/dl ) & $280-776 \quad(528)$ & $392-707 \quad(549,5)$ \\
\hline Ureum ( g/dl ) & $13-25 \quad(19,00)$ & $12-74$ \\
\hline Kreatinin & $0,4-1$ & $0,41-1,69 \quad(1,04)$ \\
\hline \multicolumn{3}{|l|}{ Kadar C3 darah } \\
\hline Menurun & 0 & 1 \\
\hline Normal & 9 & 3 \\
\hline Tidak diperiksa & 1 & 4 \\
\hline
\end{tabular}

kedua kelompok, kecuali pada 1 anak pada kelompok II dengan kadar ureum $74 \mathrm{mg} \%$. Nilai C3 normal pada 9 anak kelompok I dan 3 anak kelompok II, dan menurun pada 1 anak dari kelompok II. Biopsi tidak
1 anak kelompok I. Terdapat 4 pasien yang drop out pada kelompok I, 1 anak diantaranya meninggal dunia, sedang pada kelompok II terdapat 3 anak drop out. Dari hasil pengamatan pada kedua kelompok selama I 
tahun pasca pengobatan dilakukan analisa kesintasan. Perbandingan kurva analisa kesintasan terhadap derajat remisi pada kedua kelompok terapi dapat dilihat pada Gambar 1 dan Gambar 2. Dari kurva kesintasan terlihat pada kelompok II jumlah pasien yang tetap remisi lebih banyak dan terjadinya kekambuhan lebih lama dibandingkan kelompok I.

Jumlah kekambuhan $\geq 2$ kali dalam 6 bulan pertama terdapat pada 4 anak (40\%) kelompok I dan

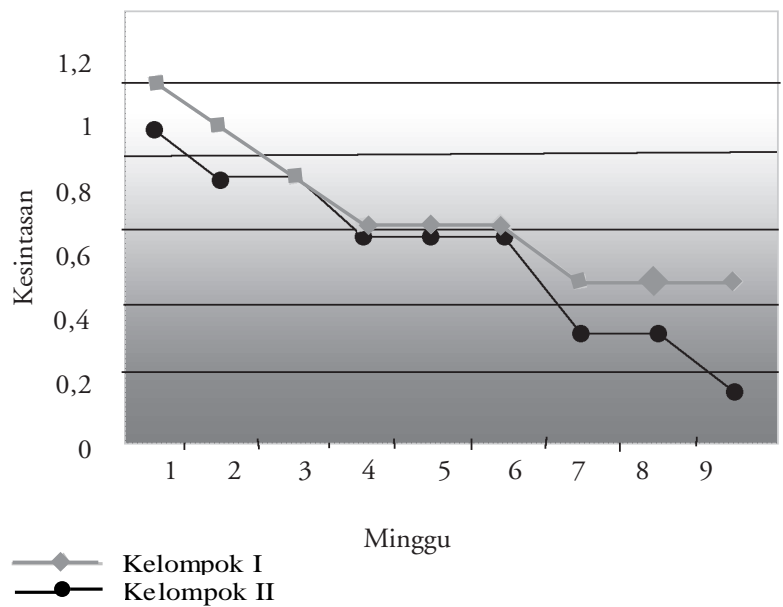

Gambar 1. Kurva kesintasan derajat remisi pasien SN dengan terapi steroid awal 8 minggu dan 12 minggu

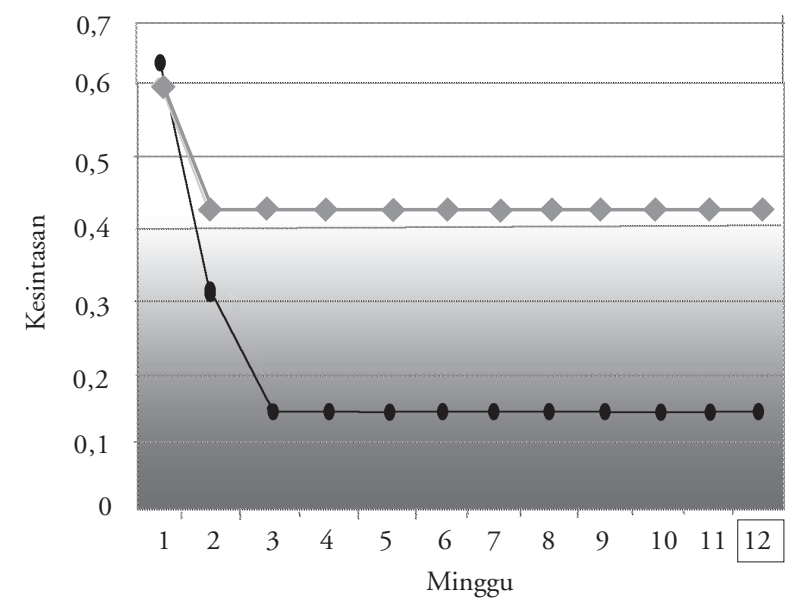

Kelompok 1

Kelompok II

Gambar 2. Kurva kesintasan derajat remisi pasien SN dengan terapi steroid awal 8 minggu dan 12 minggu
2 anak (25\%) pada kelompok II. Jumlah kekambuhan $\geq 4$ kali dalam 12 bulan pertama setelah pengobatan terjadi pada 2 anak (20\%) kelompok I dan tidak ditemukan pada kelompok II. Terdapat 1 anak (10\%) kelompok I dan 2 anak (25\%) kelompok II tidak pernah kambuh dalam 12 bulan setelah pengobatan.

\section{Diskusi}

Diagnosis sindrom nefrotik (SN) pada penelitian ini ditegakkan berdasarkan adanya proteinuria, hipoalbuminemia, dan edema serta dapat disertai hiperkolestrolemia. Namun pada saat awal diagnosis, pada beberapa anak ditemukan proteinurin semikwantitaf yang positif 1 atau 2. Hal ini terjadi karena pada saat itu anak datang sudah dalam keadaan klinis perbaikan atau edema sudah mulai berkurang.

Terdapat beberapa perbedaan yang dapat diidentifikasi pada kedua kelompok penelitian yaitu lamanya edema timbul pertama kali adanya edema anasarka, dan nilai ureum serta kreatinin. Lamanya edema timbul pertama kali bukan merupakan faktor perancu dalam penilaian kemungkinan terjadinya kekambuhan setelah pengobatan. Edema anasarka yang lebih banyak ditemukan pada kelompok I. Dalam kepustakaan disebutkan bahwa edema yang timbul lebih cepat dan progesif banyak ditemukan pada anak dengan sindrom nefrotik kelainan minimal (SNKM). ${ }^{6}$ Pada perjalanan penyakitnya SNKM memiliki prognosis yang lebih baik karena sensitif terhadap steroid. Pada kelompok II edema anasarka timbul pada 50\% anak, sedang sisanya sebenarnya juga pernah mengalami edema anasarka, yang diketahui dari riwayat penyakitnya. Rata-rata nilai ureum dan kreatinin pada kelompok II lebih tinggi, hal ini terjadi karena terdapat peningkatan ureum dan kreatinin pada 1 anak kelompok II. Penurunan fungsi ginjal pada kasus ini disebabkan retensi pada fase akut sindrom nefrotik. Hal ini ditandai dengan adanya perbaikan fungsi ginjal sesuai dengan perbaikan klinisnya.

Pada penelitian ini analisa data dilakukan dengan metode kesintasan. Penelitian ini lebih bersifat deskriptif, oleh karena jumlah sampel yang diperoleh terlampau sedikit untuk menarik kesimpulan sebab akibat. Dari perbandingan analisis kesintasan kelompok I dan kelompok II diketahui bahwa terdapat kecenderungan remisi terjadi lebih lama atau jumlah anak yang tetap dalam keadaan remisi lebih banyak 
pada kelompok II. Selain itu jumlah anak yang mengalami relaps frekuen lebih sedikit pada kelompok II. Hal ini sesuai dengan hasil pada penelitian lain. ${ }^{3,4,5}$ Kejadian relaps frekuen pada pengamatan 6 bulan pertama berturut - turut pada kelompok I dan II yaitu $40 \%$ dan 25\%. Ehrich dan Brodehl 4 melakukan penelitian dengan metode yang sama pada masingmasing 71 anak sindrom nefrotik yang baru. Mereka menemukan hasil yang hampir sama yaitu jumlah relaps frekuen $57 \%$ untuk kelompok terapi 8 bulan dan $29 \%$ untuk kelompok terapi 12 bulan. Pada penelitian ini ditemukan 10\% kelompok I dan 25\% kelompok II yang tetap dalam keadaan remisi selama 12 bulan pengamatan. Ehrich dan Brodehl 4 menemukan hasil yang sama dengan angka yang lebih tinggi yaitu jumlah yang tetap dalam keadaan remisi lebih banyak pada kelompok terapi 12 bulan (19\% vs 49\%). Penelitian ini tidak dapat dibandingkan dengan penelitian oleh Ehrich dan Brodehl oleh karena sampel dalam penelitian ini terlalu kecil.

Efek samping steroid tidak ditemukan hampir pada semua anak pada penelitian ini, kecuali pada anak kelompok I dengan toksid steroid. Brodehl hanya menemukan efek samping yang ringan pada pengobatan steroid awal selama 12 minggu.4 Sedang Ksiazek menyarankan pengobatan yang lebih lama yaitu selama 6 bulan dan selama pengobatan tersebut tidak ditemukan efek samping steroid yang berarti. ${ }^{5}$ Pengobatan steroid awal jangka panjang selama 12 minggu memang direkomendasikan mengingat keuntungannya dalam menurunkan angka kekambuhan, namun terdapat kerugian dalam hal kepatuhan penderita untuk berobat. Hal ini terlihat pada kelompok II 50\% anak tidak menyelesaikan pengobatan dan 50\% mempunyai ketaatan yang buruk. Penelitian tentang pengaruh lamanya pengobatan awal steroid pada sindrom nefrotik memang sudah banyak dilakukan. Sebagian besar peneliti menyarankan waktu pengobatan yang lebih lama dari 8 minggu. Namun masih sedikit penelitian yang mencari faktor - faktor lain yang dapat mempengaruhi seringnya kekambuhan pada perjalanan penyakit sindrom nefrotik. Faktor - faktor ini perlu diidentifikasi dalam penelitian seperti ini, agar dapat disingkirkan kemungkinan menjadi faktor perancu dalam penafsiran data.

\section{Kesimpulan}

1. Sindrom nefrotik yang mendapat terapi awal lebih lama (12 minggu) mempunyai kecenderungan lebih jarang kambuh bila dibandingkan dengan kasus yang mendapat terapi steroid awal lebih pendek (8 minggu).

2. Tidak ditemukan efek samping steroid pada kedua kelompok penelitian kecuali pada 1 anak kelompok I. Ucapan terima kasih kepada: Unit Kerja Koordinasi (UKK) Nefrologi Ikatan Dokter Anak Indonesi

\section{Daftar Pustaka}

1. International Study of Kidney Disease in Children. Nephrotic syndrome in children: a randomized trial comparing two prednisone regimens in steroid-responsive patients who relapse early. Pediatrics 1979; 95. h. 239-43.

2. International Study of Kidney Disease in Children. The primary nephrotic syndrome in children. Identification of patients with minimal change nephrotic syndrome from initial response to prednisone. J Pediatrics 1981; 98. h. 561-4.

3. Brodehl-j. Conventional therapy for idiopatic nephrotic syndrome in children. Clin- Nephrol. 1991; 35 Suppl 1:S8-15

4. Ehrich JH, Brodehl J. Long versus standard prednisone therapy for initial treatment of idiopathic nephrotic syndrome in children. Eur J Pediatr 1993; 152. h. 357-61.

5. Ksiazek J. The influence of the initial prednisone treatment period on the adrenal function and the further course of the disease in steroid sensitive nephrotic syndrome in children. Pediatr Pol 1995; 70. h. 15-23.

6. IGN Wila Wirya. Sindrom nefrotik. Dalam: Alatas H, Tambunan T, Trihono PP. Nefrologi anak; edisi ke-1. Jakarta: Balai Penerbit FKUI, 1996. h. 349-94. 